\title{
The Comparative Research on Agricultural Sector's Characteristics of Duality Economy Transition between China and Japan ${ }^{*}$
}

\author{
Ji REN \\ Labor Science and Law Institute of Beijing Wuzi University, Beijing, China
}

\begin{abstract}
Changes in the level of agricultural marginal productivity, labor force population and agricultural wages are important indicators of national economic development. By comparing the current agriculture marginal productivity and agricultural wages of China and Japan, we can educe our current stage of economic development, as well as China's labor policies should be taken to the next stage in accordance with the theory of Dual Economy transition.
\end{abstract}

KEYWORD: Agricultural marginal productivity; Agricultural wages; Duality economy transition; lewisian turning point

\section{INTRODUCTION}

China's labor market presents tremendous changes after the reform and opening-up policy. These trends represent in following factors: The significant presence of rural surplus labor in urban labor market, wage growth, capital and non-capital sector departments income gap. Also in recent years, the phenomenon of "labor shortage" arose in the eastern coastal areas of China while the agricultural sector income growth.

We can also find the similar phenomena in other East Asian developed counties and areas. Then we will discuss the experience of Japan whose duality economic structure is relatively obvious.

According to the dual economic theory, during the conversion of the country's economy from the duality economy to unitary economy, some iconic phenomenon will occurs such as surplus labor will be absorbed, the income gap between skilled and unskilled workers will be narrowed.

\section{THE THEORY AND MODEL}

\subsection{The theory}

In 1954 British economist Lewisbrought forward the dual economic model, which took the viewpoint of classic economics in explaining the process and changes of economic development.
In the early stage of the economic development the marginal labor force in agricultural sector is zero, which means unlimited supply of labor force. With the constant expansion of modern industrial sector, the surplus agricultural labor force gradually reduced, and the labor shortage began to appear. And the wages are facing upward pressure, two departments of labor market are becoming integrated.

In the second stage, labor displacement brings the reduction of the agricultural surplus and relative food shortage, along with the price of agricultural products and income level increase, which will affect the displacement of labor force from agricultural to the industrial sector. If the price increase of agricultural products causes inflation of labor costs in the industrial sector, the capitalization and expansion of the industrial sector will be restricted or even stagnated, then Lewis' second turning point will be postponed.

The above theory suggests that a country or a region will experience multitude changes in all aspects when it moves from duality economy to unitary economy.

According to the theory, this paper intends to analyze changes of agricultural labor force population, agricultural productivity and real wages. Then the paper will investigates the relationship between two variables. Finally it comes to the judgment relating to the change trends in the noncapital sector labor market.

\footnotetext{
* This research is supported by The Importation and Development of High-Caliber Talents Project of Beijing Municipal Institutions.
} 


\subsection{The data of Survey}

This paper use the household survey data to do the statistics analysis. The data collected by the Ministry of Agriculture from 1995 to 2006, comes from continuous tracking survey for 21,000 households, 650 herdsmen, 300 agricultural villages, 15 pastoral villages in the country.

Agricultural wage is used as the dependent variable, concluding the operating income in the food and cash crops from planting industry in the household operating income in the survey data. To be specific $\mathrm{L}$ is for labor date, $\mathrm{A}$ is for land area and K for capital stock.

For the agricultural wage calculation, it is mainly obtained by using the three main survey data in agricultural workers (day), worker cost and rural price index.

After statistical analysis of the data above, the average production flexibility can be obtained through regressive calculation. We can get the average agricultural productivity through the agriculture real added-value and the total agricultural labor time.

Finally, using the average productivity of agriculture and the production flexibility, we can get the agricultural marginal productivity. For the real wages level of agricultural workers, this paper applies division calculation between the annual wage of agricultural workers and price index of agricultural products.

\subsection{The model of calculation}

In the calculation of the marginal productivity of the agricultural sector, applying the Cobb - Douglas agricultural production function to estimate the production flexibility of agricultural labor.

$$
Y=A e^{\lambda t}\left(Q_{N} N\right)^{\alpha} K^{\beta}\left(Q_{L} L\right)^{\gamma}
$$

Thereinto, $Q_{N} N$ is for the labor, $\mathrm{K}$ is for the

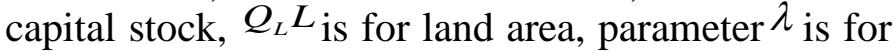
the rate of technological progress, the parameters $\alpha, \beta, \gamma$ are for the production elasticity of labor, land and capital respectively. Assumed to be linear homogeneous functions, then, $(\partial+\beta+\gamma=1)$. After rewriting logarithmic form it can be obtained by the following formula:

$$
\operatorname{In} Y_{t}=\operatorname{In} A+\lambda t+\alpha \operatorname{In}\left(Q_{N} N\right)_{t}+\beta \operatorname{In} K_{t}+\gamma \operatorname{In}\left(Q_{L} L\right)_{t}
$$

Consider the impact factors of the dependent variables, this paper takes into account the element of intermediate inputs. The crops had been separated into food crops and cash crops in order to be observed.

\section{THE TRANSITION CHARACTERISTICS IN THE AGRICULTURAL SECTOR}

\subsection{Changes of China's agricultural labor force population}

The total agricultural employment number, another characteristic of duality economics, keeps an increasing trend for the last decade in China. The rise of the rural labor migration amount caused the reduction of new surplus labor force amount. The data supported by the Ministry of agricultural and the National Bureau of Statistics shows that the rural labor migration number increases gradually in recent years. To be specific, the rural labor migration number increases from 5.066 million to 12.609 million, leading to a percentage increase from $16.0 \%$ to $27.5 \%$.

The conclusion shows, with the increasing number of rural labor migration, along with the rise of proportion of labor shift, the number of labor who enter into other industries will increase continually.

On the contrary, the surplus labor force amount will be declined gradually. In the meantime, the characteristic of dual economics get clear.

\subsection{Changes of marginal productivity and agricultural wages}

Using the above model, the agricultural productivity (food crops and cash crops) and the agricultural wages from 1995 to 2006 can be calculated, and the results were shown by fig1.

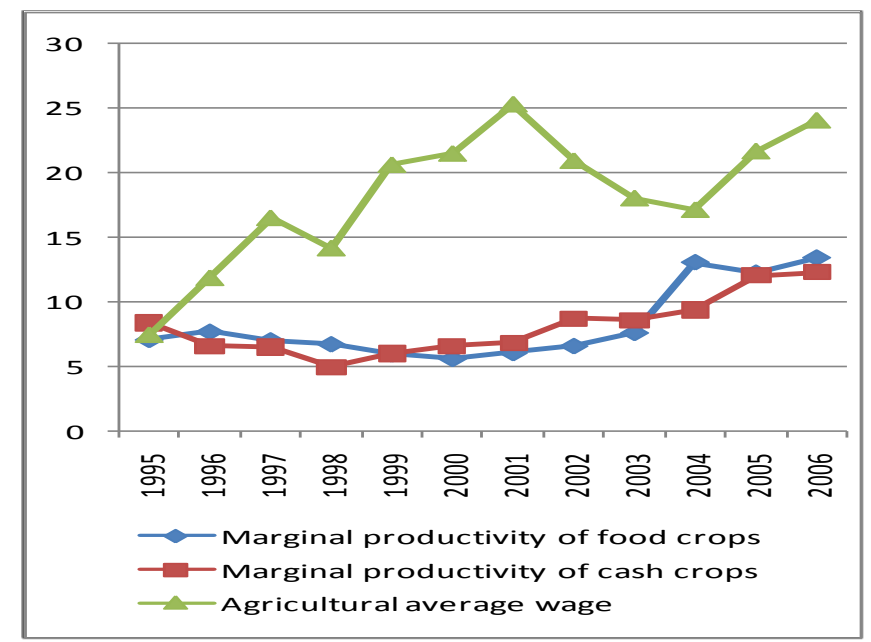

Figure 1.Changes of the agricultural real wage level and marginal productivity

From the fig.2, we can get a preliminary conclusion that Chinese agricultural wages have presented upward trend since 1995 overall. To be specific, although there was a temporary downturn relating to the agricultural wages in 2003-2004, this can be considered as a data defect caused by inconsistent standards, which was applied by the new survey method. 
Another conclusion is the marginal productivity (including the food crops and cash crops) which shows an increasing trend overall.

It is worth mentioning that the growth rate of the marginal productivity shows a big change. As shown in fig.2, the marginal productivity of food crops has increased about $6.39 \%$, and the marginal productivity of cash crops has increased about $3.91 \%$.

\section{CHANGES OF JAPAN'S LABOUR MARKET IN ITS DUALITY ECONOMIC TRANSITION PERIOD}

There are several different analysis about Japan's duality economic transition period, in this paper we follow Minami Ryoshin. Minami minutely explored Japan's marginal labor and wages in agricultural sector, agricultural labor force, the changes of the amount of non-agricultural part of the labor force and a series of other indicators, finally pointed out that Japan's Lewisian Turning Point occurred in the early 1960 s.

During this period, there was an obvious agricultural labor force shift in Japan. In the rapid development period after World War II, numerous Japanese farmers entered into non-agricultural sectors. The figure increased so sharply that it once reached an average of 50-80 million per year. The average annual change rate was 4-5\%, 3-4 times than pre-World War II.

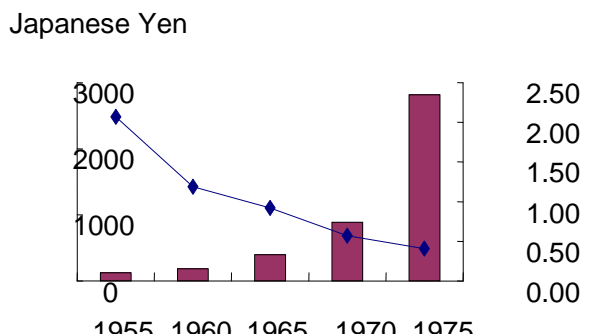

$$
\begin{aligned}
& \square \text { Income of non agriculture } \\
& - \text { rate of agricultural income }
\end{aligned}
$$

Figure2.Non-agricultural income and the rate of agricultural income

Source: Anto Yoshio. 1987. Modern Japanese Economic History. pp189.

According to the theory of Lewis model, the income growth of agricultural long-term fixed farmers illustrates that the agricultural income has break through the survival wage level. Meanwhile we can learn from the Fei, J and Ranis, G. model that the transition of the duality economy is a longperiod process. The agricultural income level is not directly through the turning point when it breaks through the survival level. Instead it will increase step by step and become close to the wage levels of other industries, which are the same as the results reflected by Diagram 4. The diagram also demonstrates a shortage of the total labor force supply in China's labor market, as well as the end of the unlimited supply of labor.

\section{CONCLUSIONS}

From the above analysis, the marginal productivity of the agricultural sector and agricultural wages in China shows the following changes between 19952006.

First, because of the shift of a plenty of agricultural labor force, the population of rural surplus labor force is declining and the era of unlimited supply of labor force is coming to the end.

Second, the average productivity and marginal productivity in the agricultural sector are increasing rapidly. The marginal productivity (average of marginal productivity of food crops and cash crops) reached $8.1 \%$ per annul averagely. Marginal productivity of food crops and cash crops shows a rapid rising trend. In particular, the marginal productivity of food crops presents a substantial increase, with an average annual growth rate of $8 \%$, an average annual $4.9 \%$ for the cash crops marginal productivity included.

Third, the wage level in the agricultural sector has been greatly improved with an annual growth rate of $13 \%$ in the last decade, with $22.5 \%$ growth rate for long-term workers and $11.4 \%$ for short-term.

Forth, the gap between the agricultural average daily wage and the average marginal productivity level is gradually narrowed. Especially after 2003, increasing marginal productivity and declining agricultural wage growth brought these two get closer.

According to the analysis of the above changes using the theory of dual economics, it shows that the marginal productivity of agriculture is infinitely closing to the level of agricultural wages.

It can speculate that, following the further improvement of the agricultural marginal productivity, the future wage level of agricultural sector will be determined by the level of marginal productivity. while surplus labor in the agricultural sector will become short. Supportive reasons lead to the conclusion that important changes in this period imply the arrival of an economical turning point in the agricultural sector. Therefore, Chinese agricultural sector should enhance the labor policy in order to conform to the needs of national economic development as a response to this trend. 


\section{REFERENCES}

[1] Lewis, W. Author(1954) Economic Development with Unlimited Supplies of Labor, Manchester School of Economic and Social Studies, 22, 2, 139-91.

[2] Ryoshin Minami (1973) The Turning Point in Economic Development: Japan's Experience, KINOKUNIYA BOOKSTORE., 147-167.

[3] CAI Fang (2007) the Lewisian Turning Point of China's Economic Development in Reports on China's Population and Labor No.8. By Social Sciences Academic Press (China).
[4] Hansen, Bent (1966) Marginal Productivity Wage Theory and Subsistence Wage Theory in Egyptian Agriculture, Journal of Development Studies, Vol.2 No.4, 367-405.

[5] Wang Dewen and REN Ji (2008)Lewisian Turning Point: International Experiences in Linking up Lewis and Kuznets turning points. By Social Sciences Academic Press(China).

[6] ANTO Yoshio. 1987. Modern Japanese Economic History. Tokyo: Tokyo University Press.

[7] WANG Dewen and REN Ji.2008. Lewisian Turning Point: International Experiences, Reports on China's population and labor No.9: Linking up Lewis and Kuznets turning point. Beijing: Social Sciences Academic Press. 